Article

\title{
Phytochemical Composition and Bioactive Effects of Salvia africana, Salvia officinalis 'Icterina' and Salvia mexicana Aqueous Extracts
}

\author{
Andrea F. Afonso ${ }^{1,2}{ }^{(D}$, Olívia R. Pereira ${ }^{3}{ }^{(0)}$, Ângela Fernandes ${ }^{3}$, Ricardo C. Calhelha ${ }^{3}{ }^{(\mathbb{C}}$, \\ Artur M. S. Silva ${ }^{1}$ (D) Isabel C.F.R. Ferreira ${ }^{3}$ (D) and Susana M. Cardoso ${ }^{1, *(D)}$ \\ 1 QOPNA \& LAQV-REQUIMTE, Department of Chemistry, University of Aveiro, 3810-193 Aveiro, Portugal; \\ andrea@ipb.pt (A.F.A.); artur.silva@ua.pt (A.M.S.S.) \\ 2 Public Health Laboratory of Bragança, Local Health Unit, Rua Eng. Adelino Amaro da Costa, \\ 5300-146 Bragança, Portugal \\ 3 Centro de Investigação de Montanha (CIMO), Instituto Politécnico de Bragança, Campus de Santa Apolónia, \\ 5300-253 Bragança, Portugal; oliviapereira@ipb.pt (O.R.P.); afeitor@ipb.pt (Â.F.); calhelha@ipb.pt (R.C.C.); \\ iferreira@ipb.pt (I.C.F.R.F.) \\ * Correspondence: susanacardoso@ua.pt; Tel.: +35-12-3437-0360; Fax: +35-12-3437-0084
}

Academic Editor: Teresa Escribano-Bailón

Received: 27 October 2019; Accepted: 22 November 2019; Published: 27 November 2019

check for updates

\begin{abstract}
In the present study, aqueous extracts of Salvia africana, Salvia officinalis 'Icterina' and Savia mexicana origin were screened for their phenolic composition and for antibacterial, antioxidant, anti-inflammatory and cytotoxic properties. The three aqueous extracts contained distinct phenolic compounds, with S. africana presenting the highest total levels $(231.6 \pm 7.5 \mu \mathrm{g} / \mathrm{mg})$. Rosmarinic acid was the dominant phenolic compound in all extracts, yet that of $S$. africana origin was characterized by the present of yunnaneic acid isomers, which overall accounted for about $40 \%$ of total phenolics. In turn, S. officinalis 'Icterina' extract presented glycosidic forms of apigenin, luteolin and scuttelarein, and the one obtained from S. mexicana contained several simple caffeic acid derivatives. S. africana aqueous extract exhibited high antioxidant potential in four methods, namely the $\mathrm{DPPH}^{\bullet}$ (2,2-diphenyl-1-picrylhydrazyl) scavenging ability, iron-reducing power, inhibition of $\beta$-carotene bleaching and of thiobarbituric acid reactive substances (TBARS), for which $\mathrm{EC}_{50}$ values were equal or only 1.3-3.1 higher than those of the standard compounds. Moreover, this extract was able to lower the levels of nitric oxide (NO) production in lipopolysaccharide (LPS)-activated RAW 264.7 macrophages $\left(\mathrm{EC}_{50}=47.8 \pm 2.1 \mu \mathrm{g} / \mathrm{mL}\right)$. In addition, the three sage aqueous extracts showed promising cytotoxic effect towards hepatocellular HepG2, cervical HeLa, and breast carcinoma cells MCF-7. Overall this study highlights the potential of three little-exploited Salvia species, with commercial value for applications in food or pharmaceutical industries.
\end{abstract}

Keywords: Salvia; phenolic compounds; high performance liquid chromatography; antioxidant; anti-inflammatory; cytotoxicity; antibacterial

\section{Introduction}

Salvia plants are distributed worldwide and are particularly prevalent in tropical and temperate zones in the Mediterranean region of Europa, South-East Asia and Central and South America [1,2]. Due to their claimed health effects, many Salvia species are considered promising for application in diverse areas, including the food, pharmaceutical and cosmetic industries [3,4]. Among the bioactive components of Salvia, terpenes, phenolic acids and flavonoids have been highlighted. In fact, on the basis of in vitro and in vivo studies, the essential oils and phenolic rich extracts of widely distributed 
species such as Salvia officinalis, Salvia miltiorrhiza and Salvia sclarea are assumed to exert potent antimicrobial, antioxidant and anti-inflammatory properties, among other beneficial effects [4-7]. Importantly, even though for the last few years there has been an increasing number of research works aiming to screen the biological properties of Salvia plants, many species and/or cultivars including S. officinalis 'Icterina', Salvia mexicana and Salvia africana (Figure 1) remain poorly explored. S. officinalis 'Icterina' is a cultivar of $S$. officinalis characterized by yellow green variegated leaves [8], but in opposition to the last species, little is known about its chemical composition and potential bioactivities. Likewise, S. mexicana (native of central Mexico [9]) is mainly known for ornamental purposes while chemical elucidation has been only focused on its essential oils [10]. In turn, S. africana (native of Africa) has long been used by african people to flavour food and as a medicinal plant to treat cold, flu, coughs and women's ailments [11,12] and its essential oil composition has been revealed [13-16], but knowledge of other bioactive metabolites remains unknown. Given the lack of information, the present study constitutes the first attempt to elucidate the phenolic composition as well as the antioxidant, anti-inflammatory, cytotoxic and antibacterial activities of aqueous extracts of $S$. officinalis 'Icterina', S. mexicana and S. africana.

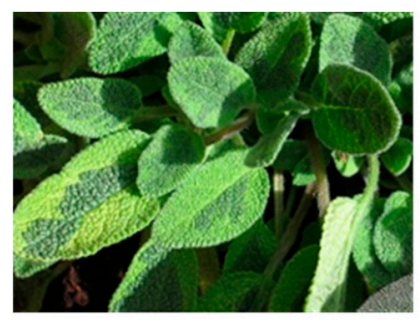

(a)

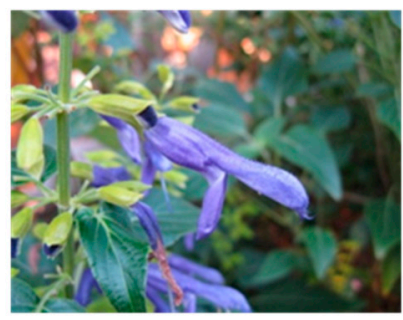

(b)

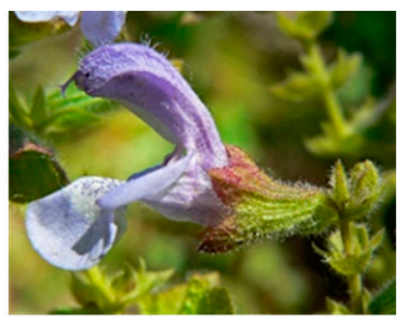

(c)

Figure 1. Salvia plants: https://pt.wikipedia.org/.

(a) S. officinalis 'Icterina'; (b) S. mexicana; (c) S. africana; retrieved from:

\section{Results and Discussion}

\subsection{Phenolic Compounds in Salvia Aqueous Extracts}

The mass yield of the three Salvia aqueous extracts ranged from 19-22\%, being also similar to those previously reported for S. elegans, S. greggii and S. officinalis L. [17]. Still, regardless of the close mass yields among the three target aqueous extracts, the total phenolic compound content in the $S$. africana extract was clearly superior than those of the two other species $(350.6 \pm 14.9 \mu \mathrm{g}$ gallic equivalents (GAE)/mg vs. $229.0 \pm 44.0$ and $158.9 \pm 38.0 \mu \mathrm{g}$ GAE/mg) (Table 1). Naturally, differences were reflected in the levels of the main phenolic component, i.e rosmarinic acid (RT $19.0 \mathrm{~min}, \mathrm{UV}_{\max }$ at $290 \mathrm{and} 328 \mathrm{~nm}$, $[\mathrm{M}-\mathrm{H}]^{-}$at $\left.m / z 359 \rightarrow 161,179,197,223\right)$, which accounted for $77.0 \pm 3.6 \mu \mathrm{g} / \mathrm{mg}$ in $S$. africana aqueous extract and $52.7 \pm 0.5$ and $29.4 \pm 0.6 \mu \mathrm{g} / \mathrm{mg}$ in those of S. officinalis 'Icterina' and S. mexicana origins, respectively. Moreover, the three extracts were also distinguishable in relation to their remaining phenolic components. S. africana was characterized by the presence of several other complex caffeic acid derivatives, particularly by distinct yunnaneic acid $\mathrm{E}$ isomers ( $\mathrm{UV}_{\max }$ at 268, 274, 276, 279, $[\mathrm{M}-\mathrm{H}]^{-}$at $m / z 571$ ), which overall accounted for $74 \mu \mathrm{g} / \mathrm{mg}$ extract (equivalent to about $32 \%$ of the total quantified phenolics). It also contained minor quantities of yunnaneic acid F (RT $14.3 \mathrm{~min},[\mathrm{M}-\mathrm{H}]^{-}$at $\mathrm{m} / \mathrm{z} 597 \rightarrow$ $579,355,312,295,197,179)$ and yunnaneic acid D (RT 15.6, and $15.9 \mathrm{~min},[\mathrm{M}-\mathrm{H}]^{-}$at $m / z$ 539), three caffeoyl rosmarinic acid isomers (RT $19.2 \mathrm{~min}, 19.5 \mathrm{~min}$ and $21.4 \mathrm{~min},[\mathrm{M}-\mathrm{H}]^{-}$at $\mathrm{m} / z$ 537), salvianolic acid $\mathrm{K}\left(\mathrm{RT} 15.1 \mathrm{~min},[\mathrm{M}-\mathrm{H}]^{-}\right.$at $\left.m / z 555 \rightarrow 313,357\right)$, salvianolic acid B (RT $18.6 \mathrm{~min},[\mathrm{M}-\mathrm{H}]^{-}$at $m / z$ $717 \rightarrow 555,519,475,357)$, and sagerinic acid (RT $17.6 \mathrm{~min},[\mathrm{M}-\mathrm{H}]^{-}$at $\left.m / z 719 \rightarrow 359,539,521,341\right)$. 
Table 1. Identification and quantification of phenolic compounds from S. africana, S. officinalis 'Icterina' and S. mexicana aqueous extracts.

\begin{tabular}{|c|c|c|c|c|c|c|c|}
\hline RT & $\mathbf{U V}_{\max }$ & {$\left[\mathbf{M}-\mathbf{H}^{-}\right.$} & MS ${ }^{2}$ Main Fragments & Probable Compound & S. $a f r^{*}$ & S. ict* & S. mex * \\
\hline 1.5 & 275 & 149 & $103,87,131,59$ & 2,4-DimethylBA & $3.4 \pm 0.2$ & $4.7 \pm 0.1$ & $5.1 \pm 0.1$ \\
\hline 1.7 & 205 & 191 & 111,173 & Quinic Ac & $\mathrm{D}$ & $0.40 \pm 0.05$ & $\mathrm{D}$ \\
\hline 3.6 & 280 & 197 & $179,73,153$ & Danshensu & $6.5 \pm 0.3$ & $\mathrm{D}$ & $3.5 \pm 0.1$ \\
\hline 4.2 & 278 & 315 & 153 & Protoc Ac Hex & $\begin{array}{c}0.0 .0 \\
-\end{array}$ & - & $\mathrm{D}$ \\
\hline 5.0 & $290 \mathrm{sh}, 324$ & 353 & $191,179,135$ & cis-3-O-CQA & - & - & $3.8 \pm 0.0$ \\
\hline 5.3 & 290,327 & 311 & 149,179 & Caftaric Ac & - & - & $3.50 \pm 0.04$ \\
\hline 8.3 & 313 & 295 & 163 & $p$-Coum Ac Pent & - & - & $0.03 \pm 0.01$ \\
\hline 8.8 & $290 \mathrm{sh}, 325$ & 353 & 191 & trans-5-O-CQA & - & - & $1.70 \pm 0.06$ \\
\hline 9.4 & ND & 325 & 163,119 & Caff Hex & - & - & $0.3 \pm 0.0$ \\
\hline 9.5 & $290 \mathrm{sh}, 325$ & 353 & $173,179,191$ & 4-O-CQA & - & - & $2.5 \pm 0.3$ \\
\hline 9.7 & $290 \mathrm{sh}, 323$ & 179 & 135 & Caff Ac & $2.3 \pm 0.1$ & $2.50 \pm 0.04$ & $0.9 \pm 0.1$ \\
\hline 11.7 & 271 & 1077 & $358,179,296,494$ & Galotannin Der & $\mathrm{D}$ & - & - \\
\hline 12.1 & 271,336 & 593 & $473,503,353$ & Api-6-C-Glc-7-O-Glc & - & $3.5 \pm 0.1$ & - \\
\hline 12.3 & 289,329 & 295 & $207,179,133,135$ & Caff Malic Ac & - & - & $1.00 \pm 0.03$ \\
\hline 12.6 & 286,320 & 313 & $269,179,135$ & SA F & - & $2.7 \pm 0.2$ & $\mathrm{D}$ \\
\hline 13.1 & 291,311 & 637 & $351,285,193$ & Ferulic Ac Der & - & $0.6 \pm 0.1$ & - \\
\hline 13.5 & 274 & 571 & $527,483,439,373$ & YA E (isomer 1) & $3.8 \pm 0.3$ & - & $4.4 \pm 0.2$ \\
\hline 13.9 & $256,267 \mathrm{sh}, 345$ & 447 & 327,357 & Lut-C-Hex & - & - & $4.1 \pm 0.2$ \\
\hline 13.9 & 281,345 & 477 & $301,373,343,397$ & Hydroxy-Lut-GlcA & $\mathrm{D}$ & $2.90 \pm 0.05$ & $\begin{array}{l}1 .+2.2 \\
-\end{array}$ \\
\hline 14.1 & 276 & 571 & $527,439,553,483$ & YA E (isomer 2) & $5.2 \pm 0.7$ & - & - \\
\hline 14.3 & 276 & 597 & $579,355,312,295,197,179$ & YA F & $8.7 \pm 0.9$ & - & - \\
\hline 14.7 & 274 & 571 & $527,509,553,483,285$ & YA E (isomer 3) & $18.3 \pm 0.9$ & - & $2.80 \pm 0.01$ \\
\hline 14.8 & 267,345 & 621 & 351,269 & Api-diGlcA & - & $\mathrm{D}$ & - \\
\hline 15.1 & 276 & 555 & 313,357 & SA K & $3.9 \pm 0.3$ & - & - \\
\hline 15.4 & 274 & 571 & $527,553,509,329$ & YA E (isomer 4) & D & - & - \\
\hline 15.6 & $235,275,320$ & 539 & $297,359,495,279$ & YA D (isomer 1) & $\mathrm{D}$ & - & - \\
\hline 15.9 & 280,333 & 461 & 285 & Scut-O-GlcA & - & $9.7 \pm 0.2$ & - \\
\hline 15.9 & 277 & 539 & $341,253,315,359$ & YA D (isomer 2) & $2.4 \pm 0.2$ & $\begin{array}{c}10.2 \\
-\end{array}$ & $3.5 \pm 0.1$ \\
\hline 16.1 & 255,266 sh, 345 & 461 & 285 & Lut-7-O-GlcA & $18.7 \pm 1.2$ & $18.2 \pm 0.4$ & - \\
\hline 16.5 & 268 & 571 & 527,409 & YA E (isomer 5) & $30.8 \pm 1.7$ & - & - \\
\hline 17.2 & 278 & 717 & $519,475,537,339$ & SA B (isomer 1) & - & - & $1.50 \pm 0.02$ \\
\hline 17.3 & 279 & 571 & $527,553,329$ & YA E (isomer 6) & $15.4 \pm 0.84$ & - & - \\
\hline 17.6 & 283 & 719 & $359,539,521,341$ & Sag Ac (isomer 1) & $6.0 \pm 0.3$ & $9.1 \pm 0.4$ & $1.20 \pm 0.01$ \\
\hline 18.1 & 269,329 & 431 & 269 & Api Hex & $\begin{array}{l}-0.0 \\
-\end{array}$ & $1.70 \pm 0.03$ & $\begin{array}{c}1.0 .01 \\
-\end{array}$ \\
\hline 18.3 & 238,341 & 607 & 299,284 & Chrys Rut & - & - & $\mathrm{D}$ \\
\hline 18.4 & 267,337 & 445 & 269,175 & Api-O-GlcA & $4.6 \pm 0.2$ & $32.8 \pm 0.5$ & - \\
\hline 18.6 & 270 & 717 & $555,519,475,357$ & SA B (isomer 2) & $3.2 \pm 0.2$ & $3.3 \pm 0.2$ & - \\
\hline $\begin{array}{l}10.0 \\
18.7\end{array}$ & $284,330 \mathrm{sh}$ & 609 & 301 & Hesperidin & $\begin{array}{c}0.2 \pm 0.2 \\
-\end{array}$ & $\begin{array}{c}0.0 \pm 0.2 \\
-\end{array}$ & $0.50 \pm 0.03$ \\
\hline 19.0 & $290 \mathrm{sh}, 328$ & 359 & $161,179,197,223$ & RA & $77.0 \pm 3.6$ & $52.7 \pm 0.5$ & $29.4 \pm 0.6$ \\
\hline 19.2 & 282 sh, 327 & 537 & 493,295 & Caff RA (isomer 1) & $3.0 \pm 0.2$ & - & - \\
\hline 19.5 & $285 \mathrm{sh}, 305$ & 537 & 493,295 & Caff RA (isomer 2) & $14.2 \pm 1.5$ & - & $1.0 \pm 0.1$ \\
\hline 19.8 & 278 & 719 & $521,341,359$ & Sag Ac (isomer 2) & - & - & $2.2 \pm 0.1$ \\
\hline 21.4 & $285 \mathrm{sh}, 330$ & 537 & $456,493,375,359$ & Caff RA (isomer 3) & $2.5 \pm 1.0$ & - & $\begin{array}{c}2.2-0.1 \\
-\end{array}$ \\
\hline & & & \multirow{2}{*}{\multicolumn{2}{|c|}{ Total Phenolic Content ${ }^{1}$}} & $231.6 \pm 7.5$ & $144.1 \pm 2.7$ & $72.8 \pm 0.7$ \\
\hline & & & & & $350.6 \pm 14.9$ & $229.0 \pm 44.0$ & $158.9 \pm 38.0$ \\
\hline
\end{tabular}

Mean values \pm S.D.; ${ }^{*}$ Values are expressed as $\mu \mathrm{g} / \mathrm{mg}$ extract; ${ }^{1}$ Determined by Folin-Ciocalteu assay and expressed as $\mu \mathrm{g}$ of gallic equivalents per $\mathrm{mg}$ of extract; D-Detected; Ac-Acid; Api-Apigenin; BA-Benzoic acid; Caff Ac-Caffeic acid; Caff-Caffeoyl; CQA-Caffeoylquinic acid; Chrys-Chrysoeriol; Coum-Coumaroyl; D-Detected; Der-Derivative; Glc-Glucoside; GlcA-Glucuronide; Hex-Hexoside; Lut-Luteolin; ND-Not determined; Pent-Pentoside; Protoc-Protocatechuic; Rut-Rutinoside; RA-Rosmarinic acid; RT-Retention time; Sag-Sagerinic; SA-Salvianolic acid; S. afr-S. africana; S. ict-S. officinalis 'Icterina'; S. mex-S. mexicana; Scut-Scutellarein; sh—shoulder; UV - Ultraviolet; YA-Yunnaneic acid.

Although some complex caffeic derivatives were also found in S. mexicana extract (yunnaneic acids E and D), this was distinguishable from the others due to the presence of several simple phenolic derivatives such as isomers of caffeoylquinic acid (RT $5.0 \mathrm{~min}, 8.8 \mathrm{~min}$ and $9.5 \mathrm{~min},[\mathrm{M}-\mathrm{H}]^{-}$at $\mathrm{m} / \mathrm{z} 353 \rightarrow 191$ ), caftaric acid (RT $5.3 \mathrm{~min},[\mathrm{M}-\mathrm{H}]^{-}$at $m / z 311 \rightarrow 149,179$ ), caffeoyl malic acid (RT $12.3 \mathrm{~min},[\mathrm{M}-\mathrm{H}]^{-}$at $m / z 295 \rightarrow 207,179,133,135$ ), sagerinic acid (RT 17.6 and $19.8 \mathrm{~min},[\mathrm{M}-\mathrm{H}]^{-}$at $\mathrm{m} / \mathrm{z} 719$ ) and the flavanone hesperidin (RT $18.7 \mathrm{~min},[\mathrm{M}-\mathrm{H}]^{-}$at $\mathrm{m} / \mathrm{z} 609 \rightarrow 301$ ). In turn, S. officinalis 'Icterina' aqueous extract was rich in flavone glycosides (accounting for about $40 \%$ of total quantified phenolic compounds), mainly represented by luteolin-O-glucuronide (RT $16.1 \mathrm{~min},[\mathrm{M}-\mathrm{H}]^{-}$at $m / z 461,18.2 \pm 0.4 \mu \mathrm{g} / \mathrm{mg}$ extract), apigenin-O-glucuronide (RT $18.4 \mathrm{~min},[\mathrm{M}-\mathrm{H}]^{-}$at $\mathrm{m} / \mathrm{z} 445 \rightarrow 269,175,32.8 \pm 0.5 \mu \mathrm{g} / \mathrm{mg}$ extract) and scutellarein-O-glucuronide (RT $15.9 \mathrm{~min},[\mathrm{M}-\mathrm{H}]^{-}$at $\mathrm{m} / \mathrm{z} 461 \rightarrow 285,9.7 \pm 0.2 \mu \mathrm{g} / \mathrm{mg}$ extract). Note that regardless of whether the major compounds herein found in S. officinalis 'Icterina' aqueous extract (rosmarinic acids, luteolin-O-glucuronide, apigenin-O-glucuronide and scutellarein-O-glucuronide) correspond to those previously reported for $S$. officinalis, the superior levels of rosmarinic acid found 
in the first one ( $52.7 \pm 0.5$ vs. $28.3 \pm 0.6 \mu \mathrm{g} / \mathrm{mg}$ extract [17]) suggests that this cultivar may be richer in rosmarinic acid compared to $S$. officinalis.

\subsection{Bioactive Properties of Salvia Aqueous Extracts}

\subsubsection{Antibacterial Activity}

The inhibitory capacities of the three Salvia aqueous extracts towards the Gram-positive bacteria Staphylococcus aureus and Staphylococcus epidermidis, and the Gram-negative bacteria Salmonella typhimurium, Escherichia coli and Pseudomonas aeruginosa, are summarized in Table 2. As reported in literature for phenolic-rich extracts in general [18,19], Gram-positive bacteria showed higher sensibility to the Salvia aqueous extracts compared to the Gram-negative pathogens, with minimum inhibitory concentration (MIC) and minimum bactericidal concentration (MBC) values of S. aureus and S. epidermidis in the range of $0.63-4.75$ and $0.94-9.50 \mathrm{mg} / \mathrm{mL}$, respectively. In fact, for these two Gram-positive strains, S. africana aqueous extract (i.e., the richest in phenolic compounds) was the most promising, with MIC and MBC values of $0.63-1.25 \mathrm{mg} / \mathrm{mL}$ and $1.25 \mathrm{mg} / \mathrm{mL}$, respectively.

Table 2. Antibacterial properties (MIC/MBC, mg/mL) of S. africana, S. officinalis 'Icterina' and S. mexicana aqueous extracts against selected test bacteria.

\begin{tabular}{ccccc}
\hline Bacteria & S. africana & S. officinalis 'Icterina' & S. mexicana & Nisin \\
\hline Staphylococcus aureus & $0.63 / 1.25$ & $0.94 / 0.94$ & $1.19 / 1.19$ & $<0.63 /<0.63$ \\
Staphylococcus epidermidis & $1.25 / 1.25$ & $3.75 / 3.75$ & $4.75 / 9.50$ & $<0.63 /<0.63$ \\
Salmonella typhimurium & $5.0 / 5.0$ & $3.75 / 3.75$ & $>9.50 />9.50$ & $0.50 / 0.50$ \\
Escherichia coli & $10.0 / 10.0$ & $7.5 / 7.5$ & $9.50 / 9.50$ & $0.50 / 1.0$ \\
Pseudomonas aeruginosa & $>10.0 />10.0$ & $7.5 / 7.5$ & $9.50 / 9.50$ & $1.0 / 1.0$ \\
\hline
\end{tabular}

MIC- minimum inhibitory concentration; MBC- minimum bactericidal concentration.

Notably, among the three aqueous extracts, that of S. officinalis 'Icterina' had a superior antibacterial capacity against Gram-negative bacteria (both MIC and MBC of 3.75 or $7.5 \mathrm{mg} / \mathrm{mL}$ ), a fact that may possibly be correlated with its unique richness in flavones, although we cannot rule out a possible contribution of non-phenolic compounds from the extract. As for the two other aqueous extracts, that of S. africana origin exhibited antibacterial ability towards S. typhimurium and E. coli, but was ineffective against $P$. aeruginosa and in turn, $S$. mexicana presented a modest antimicrobial effect against $E$. coli and P. aeruginosa and required concentrations above $9.5 \mathrm{mg} / \mathrm{mL}$ to be effective against $S$. typhimurium.

To our knowledge, literature data reporting the antimicrobial potential of polar extracts of the three Salvia species under study are restricted to S. officinalis 'Icterina'. More specifically, based on the agar disc diffusion assay, methanolic extracts of S. officinalis 'Icterina' were shown to inhibit the grown of Gram-positive and Gram-negative bacteria, for which the authors obtained inhibition hales about 9-10 $\mathrm{mm}$ at $143 \mathrm{mg} / \mathrm{mL}$ [8]. Yet, as no information was given about MIC values, a direct comparison to our results is not possible. Moreover, among studies that evaluated the antibacterial potential of Salvia polar extracts, only a few determined the MBC value, making it difficult to perceive their microbicidal potential. However, considering the previous MIC and MBC values reported by our group for aqueous extracts of Salvia apiana and Salvia farinacea var. victoria blue towards the same pathogens, we can conclude that among the six Salvia species, S. apiana is the most promising regarding antimicrobial effects (both MIC and MBC in the range 0.69-2.75 mg/mL) [20].

Also noteworthy is that the antibacterial data found herein exceeded those previously reported for Salvia extracts of distinct origins using the microdilution method. In particular, aqueous extracts of Salvia ringens [19] and Salvia amplexicaulis [18], both rich in kaempferol glycosides and/or in caffeic and rosmarinic acids, inhibited S. aureus strains (MIC of 15 and $40 \mathrm{mg} / \mathrm{mL}$, respectively) and Gram-negative bacteria (MIC of 20 to $\geq 50 \mathrm{mg} / \mathrm{mL}$ ). In turn, Toplan et al. [21] found promising results when testing a methanolic extract of Salvia veneris (rich in rosmarinic acid and luteolin glucoside), which exhibited inhibitory effect against strains of S. aureus and S. epidermidis (MIC value of 0.25 and $2.0 \mathrm{mg} / \mathrm{mL}$, respectively), 
and also against P. aeruginosa and S. typhimurium (MIC of 0.5 and $2.0 \mathrm{mg} / \mathrm{mL}$, respectively) [21]. In their research, the authors found that essential oil showed relatively weak antimicrobial activity compared to the methanol extract, underlining the antibacterial role of polar extracts.

\subsubsection{Antioxidant Activity}

The results from the antioxidant evaluation, as measured by the capacity to scavenge 2,2-diphenyl-1-picrylhydrazyl $\left(\mathrm{DPPH}^{\bullet}\right)$, to reduce ferric iron and to inhibit peroxidation events ( $\beta$-carotene bleaching and thiobarbituric acid reactive substances (TBARS) assays), are summarized in Table 3.

Table 3. Antioxidant, anti-inflammatory and cytotoxic properties of S. africana, S. officinalis 'Icterina' and S. mexicana aqueous extracts.

\begin{tabular}{|c|c|c|c|c|}
\hline Assays & S. africana & S. officinalis 'Icterina' & S. mexicana & Standard \\
\hline \multicolumn{5}{|c|}{ Antioxidant Activity $\left(\mathrm{EC}_{50}, \mu \mathrm{g} / \mathrm{mL}\right)$} \\
\hline $\mathrm{DPPH}^{\bullet}$ & $6.6 \pm 0.7^{b}$ & $10.4 \pm 0.2^{\mathrm{a}}$ & $10.0 \pm 1.1^{\mathrm{a}}$ & $6.68 \pm 0.7^{b}$ \\
\hline Ferric reducing power & $21.2 \pm 2.7^{b}$ & $42.3 \pm 3.1^{\mathrm{a}}$ & $34.0 \pm 6.5^{\mathrm{a}}$ & $16.1 \pm 2.0^{b}$ \\
\hline TBARS inhibition & $21.0 \pm 0.3^{\mathrm{c}}$ & $23.0 \pm 0.2^{b}$ & $26.2 \pm 0.9^{a}$ & $23.0 \pm 1.0^{b}$ \\
\hline$\beta$-Carotene bleaching inhibition & $128.6 \pm 6.3^{c}$ & $146.6 \pm 7.0^{\mathrm{b}}$ & $164.6 \pm 7.7^{\mathrm{a}}$ & $41.7 \pm 0.3^{d}$ \\
\hline \multicolumn{5}{|c|}{ Anti-Inflammatory Activity $\left(\mathrm{EC}_{50}, \mu \mathrm{g} / \mathrm{mL}\right)$} \\
\hline NO production inhibition & $47.8 \pm 2.1^{\mathrm{b}}$ & $60.3 \pm 1.5^{\mathrm{a}}$ & $66.3 \pm 5.4^{\mathrm{a}}$ & $16.0 \pm 1.0^{\mathrm{c}}$ \\
\hline \multicolumn{5}{|c|}{ Cytotoxic activity $\left(\mathrm{GI}_{50}, \mu \mathrm{g} / \mathrm{mL}\right)$} \\
\hline HepG2 (hepatocellular carcinoma) & $42.5 \pm 4.2^{\mathrm{a}}$ & $48.9 \pm 4.4^{\mathrm{a}}$ & $52.4 \pm 4.9^{\mathrm{a}}$ & $1.0 \pm 0.2^{b}$ \\
\hline HeLa (cervical carcinoma) & $58.8 \pm 4.5^{b}$ & $89.2 \pm 7.2^{a}$ & $61.0 \pm 5.6^{\mathrm{b}}$ & $2.0 \pm 0.1^{c}$ \\
\hline MCF-7 (breast carcinoma) & $61.3 \pm 9.8^{\mathrm{a}}$ & $71.0 \pm 3.4^{\mathrm{a}}$ & $66.2 \pm 4.6^{\mathrm{a}}$ & $1.0 \pm 0.04^{b}$ \\
\hline NCI-H460 (non-small cell lung cancer) & $286.6 \pm 17.6^{\mathrm{a}}$ & $273.3 \pm 14.3^{\mathrm{a}}$ & $257.6 \pm 21.4^{\mathrm{a}}$ & $1.0 \pm 0.1^{b}$ \\
\hline PLP2 (non-tumour cells) & $336.4 \pm 10.8^{a}$ & $304.9 \pm 11.1^{\mathrm{a}}$ & $296.8 \pm 7.3^{\mathrm{a}}$ & $3.0 \pm 1.0^{b}$ \\
\hline
\end{tabular}

$\mathrm{DPPH}^{\bullet}$-2,2-diphenyl-1-picrylhydrazyl radical; NO-nitric oxide; TBARS-thiobarbituric acid reactive substances. Ascorbic acid and butylated hydroxyanisole (BHA) were used as reference compounds in DPPH and ferric reducing power assays, respectively; Trolox was used as reference compound in the both TBARS and $\beta$-carotene inhibition methods; Dexamethasone and ellipticine were used as reference compounds in anti-inflammatory and cytotoxicity activities, respectively. Means followed by the same letters $(a, b, c, d)$ in rows do not differ by Tukey's test $(p>0.05)$.

Amongst the three plant aqueous extracts, that of $S$. africana was the most active, exhibiting similar potency to that of standard compounds in $\mathrm{DPPH}^{\bullet}$, ferric reducing power and TBARS methods, a fact that may be associated to its richness in phenolic compounds, as previously described for plants extracts. In fact, methanolic extracts of $S$. officinalis [22,23], rich in glycosidic flavones, rosmarinic acids and caffeic acid derivatives, together with other polar extracts of several Salvia species that had high content in flavonoid compounds (e.g., luteolin, apigenin, quercetin and their glycosides) $[18,22,24-26]$, were shown to be promising antioxidant agents.

Concerning the two other sage aqueous extracts under study, the results varied among the assays, possibly as a reflect of their different compositions and the distinct mechanisms of action involved. In fact, although they showed the same ability to scavenge the DPPH${ }^{\bullet}$ and to reduce $\mathrm{Fe}^{3+}$, that of $S$. officinalis 'Icterina' was significantly more efficient in protecting against lipid peroxidation events in $\beta$-carotene bleaching inhibition test. Yet, overall, one must highlight the high potential of the three Salvia extracts regarding the prevention of oxidative-related events, as evidenced by their $\mathrm{EC}_{50}$ values which were in the same order or, in maximum, 4 times over those of trolox.

Also of note, the results herein gathered surpassed that previously described for a $S$. africana extract obtained with methanol:chloroform (1:1), for which $\mathrm{DPPH}^{\bullet} \mathrm{EC}_{50}$ value was reported to be $33.4 \pm 3.73 \mu \mathrm{g} / \mathrm{mL}$ and equivalent to 13.3-fold that of the positive control trolox [14]. As far as we know, there is no literature data regarding the antioxidant abilities of aqueous extracts of $S$. mexicana and S. officinalis 'Icterina' origin. Yet, it is curious that the potential of S. officinalis 'Icterina' aqueous extract to scavenge DPPH ${ }^{\bullet}$ was 3 times above than that of $S$. officinalis $\left(\mathrm{EC}_{50}\right.$ of $10.4 \mathrm{vs} .34 .8 \mu \mathrm{g} / \mathrm{mL}$, respectively) [17], suggesting that 'Icterina' cultivar may be more active than $S$. officinalis in scavenging free radicals. 


\subsubsection{Anti-Inflammatory Activity}

Due to its relevance in inflammatory events, the radical nitric oxide (NO) is considered to be a key target for anti-inflammatory agents [27]. In this sense, the ability of the three Salvia aqueous extracts to act as inhibitory agents of nitric oxide production by activated macrophages was assessed in the lipopolysaccharide (LPS)-stimulated RAW 264.7 macrophage cell model. As shown in Table 3, S. africana had the most promising activity, which corresponded to about 3-fold that of dexamethasone used as a reference compound ( $\mathrm{EC}_{50}$ of $47.8 \pm 2.1 \mu \mathrm{g} / \mathrm{mL}$ vs. $16.0 \pm 1.0 \mu \mathrm{g} / \mathrm{mL}$, respectively), while S. officinalis 'Icterina' and S. mexicana showed close efficacies, albeit tending to be superior in the first one ( $\mathrm{EC}_{50}$ values of 60.3 and $66.3 \mu \mathrm{g} / \mathrm{mL}$, respectively), also following the same tendency as for their levels of phenolic compounds. Note that the ability of Salvia polar extracts to act towards NO has been scarcely studied. However, we have previously underlined the scavenging capacity of this radical by S. officinalis, S. elegans and S. greggii aqueous extracts, as estimated in chemical assay [17], as well as the efficacy of S. apiana and S. farinacea var. victoria blue to reduce NO production in the same macrophage cellular model ( $\mathrm{EC}_{50}=49.9$ and $80.8 \mu \mathrm{g} / \mathrm{mL}$, respectively) [20]. Also, commercial aqueous extracts of S. miltiorrhiza $[28,29]$ and ethanolic extracts of Salvia plebeia [30] were previously shown to modulate levels of NO by activated RAW 264.7 macrophage cells, in a concentration-dependent manner, albeit for high $\mathrm{EC}_{50}$ values (of $200 \mu \mathrm{g} / \mathrm{mL}$ and higher than $500 \mu \mathrm{g} / \mathrm{mL}$, respectively).

Notably, although no in vivo anti-inflammatory activity of the herein target plants were previously reported, several Salvia species were shown to act as anti-inflammatory agents. E.g., methanolic extracts obtained from sage species (Salvia halophila, Salvia virgata, Salvia splendens, Salvia fruticosa and Salvia bicolor), all rich in phenolic acids (caffeic, rosmarinic, o-coumaric, gallic acid), and/or flavonoids, particularly luteolin and apigenin in glyosidic or aglycone forms, were described to reduce carrageenan-induced paw edema in rat models [31-34]. Likewise, a decrease in the levels of cytokines IL-6, IL-1 $\beta$ and TNF- $\alpha$ were reported after oral administration of ethanolic extract from $S$. sclarea in a rat model of periodontal disease, a fact that authors have associated to its high content in rosmarinic acid [24]. Importantly, inhibition of production and mRNA expression of cytokines IL-6, IL-1 $\beta$, and TNF- $\alpha$ in stimulated THP-1 macrophages were already demonstrated for lithospermic acid extracted from the root of S. miltiorrhiza [35], thus highlighting their central role on the anti-inflammatory properties of these plants.

\subsubsection{Cytotoxic Activity}

The cytotoxic ability of the three Salvia extracts on tumor and non-tumor cell lines was carried out by the sulforhodamine B (SRB) test, which allows estimation of the number of metabolically active cells present in culture. Similarly to our results previously reported for S. apiana and S. farinacea var. vitoria blue [20], the present data confirms promising cytotoxic effects of S. africana, S. officinalis 'Icterina' and S. mexicana aqueous extracts against hepatocellular carcinoma HepG2, cervical carcinoma HeLa and breast carcinoma MCF-7 cells, as well their tumor-selectivity as reflected by comparatively low $\mathrm{GI}_{50}$ values in the cancer cell lines compared to those of non-tumoral PLP2 cells (Table 3). Overall, the three extracts showed similar cytotoxicity $(p>0.05)$, except for the extract from S. officinalis 'Icterina' against HeLa cells, which showed significantly lower activity than the others. As far as we are aware, the potential cytotoxic effect of the present target Salvia species has not been exploited before and since, our results represent the first alert for their potency to serve as anti-tumoral agents. Thus, although we cannot directly compare our results with others previously reported (once different extracts, controls and methods have been used), the results presented herein emphasizes the potential of sage polar extracts in tumoral cell inhibition. The cytotoxic effect of ethanolic extracts from leaves and roots of S. officinalis on HepG2 cells after $24 \mathrm{~h}$ of exposure was evaluated by Jiang et al. [36], showing half maximal inhibition concentration $\left(\mathrm{IC}_{50}\right.$ ) values of 84.0 and $75.8 \mu \mathrm{g} / \mathrm{mL}$, respectively. In that study, both extracts exhibited less anti-proliferation ability in normal human liver cells (WRL-68), with higher $\mathrm{IC}_{50}$ values $(>100 \mu \mathrm{g} / \mathrm{mL})$ compared with the effect on HepG2 cells [36]. Similarly, Shahneh et al. [37] reported an inhibitory effect of a crude methanolic extract of $S$. officinalis against tumor cell lines, as 
reflected by the comparatively low $\mathrm{IC}_{50}$ values when exposed to MCF-7 cells ( $142 \mu \mathrm{g} / \mathrm{mL}$ ), to that obtained towards Human Umbilical Vein Endothelial Cells (HUVEC, IC ${ }_{50}$ values exceeding $600 \mu \mathrm{g} / \mathrm{mL}$ ).

\section{Materials and Methods}

\subsection{Chemicals}

Rosmarinic acid, the 7-O-glucoside derivatives of apigenin, luteolin and eriodictyol, caffeic acid, 5-O-caffeoylquinic acid, 4-O-hydroxybenzoic acid, salvianolic acid B, ferulic acid, and 4-O-coumaric acid were obtained from Extrasynthese (Genay Cedex, France). Gallic acid, nisin, ascorbic acid, trolox, sulforhodamine B (SRB), DPPH ${ }^{\bullet}$ (2,2-diphenyl-1-picrylhydrazyl) radical, acetic acid, ellipticine, trypan blue, trichloroacetic acid (TCA), Tris, lipopolysaccharide (LPS), nisin, and butylated hydroxyanisole (BHA) were obtained from Sigma Chemical Co (St Louis, MO, USA). Folin-Ciocalteu reagent, $\mathrm{Na}_{2} \mathrm{CO}_{3}$, formic acid and ethanol were purchased from Panreac (Barcelona, Spain). n-hexane, methanol and acetonitrile with high-performance liquid chromatography (HPLC) purity were purchased from Lab-Scan (Lisbon, Portugal). Fetal bovine serum (FBS), L-glutamine, trypsin-ethylenediaminetetraacetic acid (EDTA), penicillin/streptomycin solution (100 U/mL and $100 \mathrm{mg} / \mathrm{mL}$, respectively), RPMI 1640 and DMEM media were obtained from Hyclone (Logan, Utah, UT, USA). The Griess reagent system was purchased from Promega Corporation (Madison, WI, USA). Mueller-Hinton agar was purchased from VWR (Prolabo Chemicals, West Chester, PA, USA). Purified water was obtained from a Direct-Q ${ }^{\circledR}$ water purification system (Merck Life Science, Darmstadt, Germany).

\subsection{Plant Material}

The S. africana, S. officinalis 'Icterina' and S. mexicana species were collected from the fields of Coimbra College of Agriculture, Portugal, GPS coordinates 40.211439, -8.451251. After collection, its aerial parts were dried in a ventilated incubator at $35^{\circ} \mathrm{C}$ for 3 days and kept in a dark room until use.

\subsection{Extraction of Phenolic Compounds}

The extraction of phenolic compounds was performed according to the method described by Ferreira et al. [38] with adaptations. Briefly, $0.5 \mathrm{~mm}$ mesh powder of the aerial parts (flowers, leaves and stems) of S. africana, S. officinalis 'Icterina' and S. mexicana ( $5 \mathrm{~g})$ was extracted for 15 min using a decoction 1:20 (5 g in $100 \mathrm{~mL}$ of water), filtrated and concentrated using a rotary evaporator (BUCHI Labortechnik AG, Flawil, Switzerland). The resulting filtrated solution was concentrated in a rotary evaporator at $37^{\circ} \mathrm{C}$, followed by defatting with $n$-hexane $(1: 1 \mathrm{v} / v)$. The resulted fraction was frozen, freeze-dried and kept under vacuum in a desiccator in the dark, for subsequent use. This procedure was performed as three independent assays.

\subsection{Identification and Quantification of Phenolic Compounds}

The total phenolic content of each Salvia extract was determined according to the adapted Folin-Ciocalteu colorimetric method and expressed as $\mu \mathrm{g}$ of gallic equivalents (GAE) per mg of extracts, as described by Pereira et al. [39]. The phenolic profile of the aqueous extracts was determined by liquid chromatography analysis using an Ultimate 3000 (Dionex Co., San Jose, CA, USA) apparatus equipped with an ultimate 3000 Diode Array Detector (Dionex Co., San Jose, CA, USA) and a Thermo LTQ XL mass spectrometer (Thermo Scientific, San Jose, CA, USA), following a method described by Afonso et al. [40]. Gradient elution was carried out with a mixture of $0.1 \%(v / v)$ of formic acid in water (solvent A) and acetonitrile (solvent B). The solvent gradient used consisted of a series of linear gradients starting from $5 \%$ of solvent $B$ and increasing to $23 \%$ at $14.8 \mathrm{~min}$, to $35 \%$ at $18 \mathrm{~min}$, and to $100 \%$ at $21 \mathrm{~min}$ over three minutes, followed by a return to the initial conditions. Operations of the mass spectrometer were carried out using the conditions previously described [41].

Rosmarinic acid and other less expressive compounds (trans-5-O-caffeoylquinic acid, caffeic acid and salvianolic acid B) were identified using standard commercial compounds. In cases that 
standard commercial compound was not available (e.g., yunnaneic acid E), identification of the phenolic component was based on the interpretation of ultraviolet (UV) spectral and mass spectrometry (MS) data, plus comparison to literature. Quantification was performed by the external standard method using the calibration curves of structurally related standard compounds. Rosmarinic acid was used to quantify rosmarinic acid and caffeoylrosmarinic acid isomers; 5-O-caffeoylquinic acid was used to quantify caffeoylquinic acids while other caffeic acid derivatives were quantified as equivalents of caffeic acid; salvianolic acid B was used to quantify salvianolic acid B isomers, yunnaneic acid isomers and sagerinic acid isomers; 2,4-dimethyl benzoic acid was quantified with 4-O-hydroxybenzoic acid; ferulic acid derivatives and coumaric acid derivatives were quantified as equivalents of ferulic acid and 4-O-coumaric acid, respectively; luteolin glycosides, apigenin and its glycosides, and hesperidin, were quantified as equivalents of luteolin-7-O-glucoside, apigenin-7-O-glucoside and eriodictyol-7-O-glucoside, respectively; Depending on the UVmax of each compound, the quantification was performed at 280,320, or $340 \mathrm{~nm}$, also considering the limit of detection (LOD) and limit of quantification (LOQ). LOD and LOQ were determined from the parameters of the calibration curves, being defined as 3.3 and 10 times the value of the regression error divided by the slope, respectively [40].

\subsection{Antibacterial Activity}

The antibacterial potentials of the S. africana, S. officinalis 'Icterina' and S. mexicana species were evaluated against five bacterial strains, including Gram-positive bacteria (S. epidermidis NCTC 11,047 and S. aureus NCTC 6571) and Gram-negative bacteria (S. typhimurium NCTC 12023, E. coli NCTC 9001, and P. aeruginosa NCTC 10662) from the National Collection of Type Cultures (NCTC), operated by Public Health England, Salisbury, United Kingdom. All strains were cultured in Mueller-Hinton agar and incubated at $37^{\circ} \mathrm{C}$ for $24 \mathrm{~h}$. The minimum inhibitory concentration (MIC) and minimum bactericidal concentration (MBC) of aqueous solutions of three Salvia species were determined by the broth microdilution method using an adapted method previous described by Afonso et al. [40]. MIC is defined as the lowest concentration at which visible growth is inhibit, while MBC is the lowest concentration of the tested substance which has a bactericidal effect. Briefly, bacterial suspensions were prepared by direct colony suspensions and a final inoculum of $1.5 \times 10^{5}$ colony forming units $(\mathrm{CFU}) / \mathrm{mL}$ was required for final suspensions that was diluted in a 1:100 ratio in Mueller-Hinton broth. Next, $100 \mu \mathrm{L}$ of this medium was dispensed into wells of 96-well micro titer plates and Salvia aqueous extracts were added and serially diluted four times across the plate. Then, $100 \mu \mathrm{L}$ of bacteria suspension was added to each well and the plates were incubated at $37^{\circ} \mathrm{C}$ for $24 \mathrm{~h}$. The assay for each pathogen was repeated three times. MBC values are determined by sub-culturing from each negative well onto Mueller-Hinton agar and confirmation the lowest concentration with no visible growth [42]. Nisin was used as the positive control.

\subsection{Antioxidant Activity}

\subsubsection{2,2-Diphenyl-1-Picrylhydrazyl Radical ( $\mathrm{DPPH}^{\bullet}$ ) Scavenging Test}

The extracts capacity $(0.002-0.02 \mathrm{mg} / \mathrm{mL})$ for scavenging DPPH ${ }^{\bullet}$ was evaluated following the procedure previously described by Catarino et al. [43]. Ascorbic acid was used as positive control and the results were expressed as $\mathrm{EC}_{50}$ values (sample concentration providing $50 \%$ of antioxidant activity, i.e., concentration of the extract able to inhibit the $50 \%$ of the DPPH radical).

\subsubsection{Reducing Power Test}

The ability of the three sage extracts to reduce iron(III) to iron(II) was carried out according to a procedure described before [43], in which the antioxidant compounds from the extracts $(0.008-0.045 \mathrm{mg} / \mathrm{mL})$ form a colored complex with potassium ferricyanide, trichloroacetic acid, and ferric chloride, measurable 
at $700 \mathrm{~nm}$. BHA (butylated hydroxyanisole) was used as positive control and the results were expressed as $\mathrm{EC}_{50}$ values, corresponding to 0.5 of absorbance.

\subsubsection{Thiobarbituric Acid Reactive Substances (TBARS)}

The TBARS assay was evaluated for the extracts $(0.0195-0.625 \mathrm{mg} / \mathrm{mL})$ by the inhibition of lipid peroxidation in porcine (Sus scrofa) brain homogenates, according to a procedure described by Martins et al. [44]. The color intensity of the malondialdehyde-thiobarbituric acid (MDA-TBA) was measured as its absorbance at $532 \mathrm{~nm}$; the inhibition ratio (\%) was calculated using the following equation: $[(\mathrm{A}-\mathrm{B}) / \mathrm{A}] \times 100 \%$, where $\mathrm{A}$ and $\mathrm{B}$ were the absorbance of the control and the sample solutions, respectively. Trolox was used as positive control and the results were expressed as $\mathrm{EC}_{50}$ values, i.e., concentration of the extract able to inhibit peroxidation by $50 \%$.

\subsection{4. $\beta$-Carotene Bleaching Inhibition Assay}

$\beta$-carotene linoleate general assay was performed as described by Barros et al. [45], evaluating the $\beta$-carotene bleaching inhibition capacity of samples $(0.039-0.312 \mathrm{mg} / \mathrm{mL})$. Trolox was used as positive control and the results were expressed as $\mathrm{EC}_{50}$ values i.e., concentration of the extract able to inhibit peroxidation by $50 \%$.

\subsection{Anti-Inflammatory Activity}

The extracts ability in scavenging the NO was evaluated in the mouse macrophage-like cell line RAW 264.7 following the general procedure previously described [46]. Cells were treated under $5 \% \mathrm{CO}_{2}$ in humidified air, using DMEM culture medium enriched with $10 \%$ heat inactivated fetal bovine serum, glutamine, and antibiotics at $37^{\circ} \mathrm{C}$. For the tests, cells were seeded in 96 -well plates (150,000 cells/well) and allowed do attach to the plate overnight. Then, these were treated with extract solutions (concentration between 25 and $100 \mu \mathrm{g} / \mathrm{mL}$, for each extract) for $1 \mathrm{~h}$, followed by the stimulation with LPS $(1 \mu \mathrm{g} / \mathrm{mL})$ for $18 \mathrm{~h}$. The effect of all the tested samples in the absence of LPS was also evaluated, in order to observe if they induced changes in NO basal levels. Dexamethasone $(50 \mu \mathrm{M})$ was used as a positive control while negative controls had no added LPS. The NO levels produced were determined by the Griess reaction, used for measuring the nitrite accumulation in the culture supernatant on macrophage cell line RAW 264.7 [46]. The anti-inflammatory activity of each extract was determined by calculating $\mathrm{EC}_{50}$ values $(\mu \mathrm{g} / \mathrm{mL})$, which correspond to the sample concentration that provides $50 \%$ inhibition of $\mathrm{NO}$ production.

\subsection{Cytotoxicity in Tumor Cell Lines and Primary Porcine Liver Cells}

The cytotoxic effect of the three Salvia species towards four human tumor cell lines were carried out by the sulforhodamine B (SRB) assay, using the conditions established by Souza et al. [46]. The tumor cell lines MCF-7 (breast adenocarcinoma), NCI-H460 (non-small cell lung cancer), HeLa (cervical carcinoma), and HepG2 (hepatocellular carcinoma), were maintained in enriched medium, at $37^{\circ} \mathrm{C}$, in a humidified air incubator containing $5 \% \mathrm{CO}_{2}$. Each cell line was plated at an appropriate density $\left(7.5 \times 10^{3}\right.$ cells/well for MCF-7 and NCI-H460 or $1.0 \times 10^{4}$ cells/well for HeLa and HepG2) in 96-well plates. The cytotoxicity of the sage extracts were also tested by hepatotoxicity assay, in a primary non-tumor cell culture obtained from porcine liver (PLP2) following the procedures described [46]. For the tests, cells were seeded (at $1.0 \times 10^{4}$ cells/well) in enriched medium. The cytotoxicity results were expressed as $\mathrm{GI}_{50}$ values $(\mu \mathrm{g} / \mathrm{mL})$, corresponding to sample concentration that inhibited $50 \%$ of the cell growth. Ellipticine was used as positive control.

\subsection{Statistical Analysis}

The results were analyzed using GraphPad Prism 6 (GraphPad Software, San Diego, CA, USA). Data were expressed as mean \pm S.D. of 3-4 independent experiments performed at least in triplicate. 
One-way analysis of variance (ANOVA) followed by Tukey's test was used to detect any significant differences among different means. The $p$-value less than 0.05 were assumed as significant difference.

\section{Conclusions}

The phenolic composition of S. africana, S. officinalis 'Icterina' and S. mexicana aqueous extracts were assessed and their biological benefits evaluated. The three aqueous extracts were mainly characterized by distinct amounts of phenolic acids and flavonoids, which can be hypothesized to be partially related to their biological activities. In particular, one can emphasize the antioxidant, anti-inflammatory and cytotoxic potentials of $S$. africana. The aqueous extract of this species exhibited similar potency to that of positive controls in $\mathrm{DPPH}^{\bullet}$, ferric reducing power and TBARS methods, and was also promising regarding the ability to inhibit the production of NO by LPS-stimulated RAW 264.7 macrophages cells $\left(\mathrm{EC}_{50}=47.8 \pm 2.1 \mu \mathrm{g} / \mathrm{mL}\right)$. Moreover, it showed a tendency to high cytotoxicity towards tumoral cells (hepatocellular HepG2, cervical HeLa and breast MCF-7 carcinoma cell lines) when compared to normal cells, underlining its probable selectivity. In turn, consistent with the low phenolic content in S. mexicana aqueous extract, this was the least promising regarding most activities, a fact that could reinforce the involvement of phenolic compounds in such effects. S. officinalis 'Icterina' aqueous extract presented high content of glyosidic flavones and exhibited antibacterial potential with inhibitory and lethal effect against Gram-positive (MIC and MBC of 0.94-3.75 mg/mL) and Gram-negative bacteria (MIC and MBC in the range 3.75-7.5 mg/mL). Overall, this study suggests health-promoting effects from Salvia aqueous extracts, particularly for S. africana, albeit further investigation is needed using cellular/in vivo models, in order to prove this hypothesis and to elucidate their targets of inhibition on events of oxidation, inflammatory and apoptotic or necrotic death.

Author Contributions: A.F.A. contribution to investigation, data curation, and writing the original draft. O.R.P. contribution to conceptualization, data curation, supervision, and Writing-Review and editing. Â.F. contribution to investigation (antioxidant assays). R.C.C. contribution to investigation (cellular assays), Writing-Review and editing. A.M.S.S. contribution to resources and Writing-Review. I.C.F.R.F. contribution to conceptualization, resources and Writing-Review. S.M.C. contribution to conceptualization, data curation, supervision, resources and writing - review.

Funding: Foundation for Science and Technology (FCT), the European Union, the National Strategic Reference Framework (QREN), the European Regional Development Fund (FEDER), and Operational Programme Competitiveness Factors (COMPETE), for funding the Organic Chemistry Research Unit (QOPNA) (FCT UID/QUI/00062/2019) and Mountain Research Center (CIMO) (UID/AGR/00690/2019), through national funds and where applicable co-financed by the FEDER, within the PT2020 Partnership Agreement. A. Fernandes and R. Calhelha thank the national funding by FCT, P.I., through the institutional scientific employment program-contract. Project AgroForWealth (CENTRO-01-0145-FEDER-000001), funded by Centro2020, through FEDER and PT2020, financed the research contract of Susana M. Cardoso. APC was sponsored by MDPI.

Acknowledgments: We acknowledge Eng. Filipe Melo from the School of Agriculture of the Polytechnic Institute of Coimbra, for providing the plant material.

Conflicts of Interest: The authors declare no conflict of interest.

\section{References}

1. Karousou, R.; Hanlidou, E.; Kokkini, S. The Sage Plants of Greece: Distribution and Infraspecific Variation. In Sage, the Genus Salvia; Kintzios, S.E., Ed.; Taylor \& Francis e-Library: Amsterdam, The Netherlands, 2005; pp. 27-46, ISBN 0-203-34348-4.

2. Dweck, A.C. Introduction. The Folklore and Cosmetic Use of Various Salvia Species. In Sage, the Genus Salvia; Kintzios, S.E., Ed.; Taylor \& Francis e-Library: Amsterdam, The Netherlands, 2005; pp. 1-25, ISBN 0-203-34348-4.

3. Carović-Stanko, K.; Petek, M.; Grdiša, M.; Pintar, J.; Bedeković, D.; Ćustić, M.H.; Satovic, Z. Medicinal plants of the family lamiaceae as functional foods-A review. Czech J. Food Sci. 2016, 34, 377-390. [CrossRef]

4. Ozkan, G.; Kamiloglu, S.; Ozdal, T.; Boyacioglu, D.; Capanoglu, E. Potential use of Turkish medicinal plants in the treatment of various diseases. Molecules 2016, 21, 257. [CrossRef] [PubMed]

5. Jakovljevic, M.; Jokic, S.; Molnar, M.; Jašic, M.; Babic, J.; Jukic, H.; Banjari, I. Salvia officinalis L. Preparations. Plants 2019, 8, 55. [CrossRef] [PubMed] 
6. Jassbi, A.R.; Zare, S.; Firuzi, O.; Xiao, J. Bioactive phytochemicals from shoots and roots of Salvia species. Phytochem. Rev. 2016, 15, 829-867. [CrossRef]

7. Ghorbani, A.; Esmaeilizadeh, M. Pharmacological properties of Salvia officinalis and its components. J. Tradit. Complement. Med. 2017, 7, 433-440. [CrossRef] [PubMed]

8. Pop, A.; Tofană, M.; Socaci, S.A.; Pop, C.; Rotar, A.M.; Salanţă, L. Determination of Antioxidant Capacity and Antimicrobial Activity of Selected Salvia Species. Bull. UASVM Food Sci. Technol. 2016, 73. [CrossRef]

9. Arizmendi, M.; Constanza, M.; Lourdes, J.; Ivonne, F.; Edgar, L. Effect of nectar feeders over diversity and abundance of S. mexicana and S. fulgens in a sub-urban park next to Mexico City. Biol. Conserv. 2007, 136, 155-158. [CrossRef]

10. Frontana-Uribe, B.A.; Escárcega-Bobadilla, M.V.; Estrada-Reyes, R.; Morales-Serna, J.A.; Salmón, M.; Cárdenas, J. A new languidulane diterpenoid from Salvia mexicana var. mexicana. Molecules 2011, 16, 8866-8873. [CrossRef]

11. S. africana. Available online: http://pza.sanbi.org/salvia-africana (accessed on 13 July 2019).

12. Kamatou, G.P.P.; Makunga, N.P.; Ramogola, W.P.N.; Viljoen, A.M. South African Salvia species: A review of biological activities and phytochemistry. J. Ethnopharmacol. 2008, 119, 664-672. [CrossRef]

13. Kamatou, G.P.P.; Van Zyl, R.L.; Vuuren, S.F. Van Chemical Composition, Leaf Trichome Types and Biological Activities of the Essential Oils of Four Related Salvia Species Indigenous to Southern Africa. J. Essent. Oil Res. 2006, 18, 72-79. [CrossRef]

14. Kamatou, G.P.P.; Viljoen, A.M.; Steenkamp, P. Antioxidant, antiinflammatory activities and HPLC analysis of South African Salvia species. Food Chem. 2010, 119, 684-688. [CrossRef]

15. Martino, L.; Roscigno, G.; Mancini, E.; Falco, E.; Feo, V. Chemical Composition and Antigerminative Activity of the Essential Oils from Five Salvia Species. Molecules 2010, 735-746. [CrossRef] [PubMed]

16. Kamatou, G.P.P.; Van Zyl, R.L.; Van Vuuren, S.F.; Figueiredo, A.C.; Barroso, J.G.; Pedro, L.G.; Viljoen, A.M. Seasonal variation in essential oil composition, oil toxicity and the biological activity of solvent extracts of three South African Salvia species. South African J. Bot. 2008, 74, 230-237. [CrossRef]

17. Pereira, R.; Catarino, M.D.; Afonso, A.F.; Silva, A.M.S.; Cardoso, S.M. Salvia elegans, Salvia greggii and Salvia officinalis Decoctions: Antioxidant Activities and Inhibition of Carbohydrate and Lipid Metabolic Enzymes. Molecules 2018, 23, 3169. [CrossRef]

18. Alimpić, A.; Knežević, A.; Milutinović, M.; Stević, T.; Šavikin, K.; Stajić, M.; Marković, S.; Marin, P.D.; Matevski, V.; Duletić-Laušević, S. Biological activities and chemical composition of Salvia amplexicaulis Lam. extracts. Ind. Crops Prod. 2017, 105, 1-9. [CrossRef]

19. Alimpić, A.; Pljevljakušić, D.; Šavikin, K.; Knežević, A.; Ćurčić, M.; Veličković, D.; Stević, T.; Petrović, G.; Matevski, V.; Vukojević, J.; et al. Composition and biological effects of Salvia ringens (Lamiaceae) essential oil and extracts. Ind. Crops Prod. 2015, 76, 702-709. [CrossRef]

20. Afonso, A.F.; Pereira, O.R.; Fernandes, Â.S.F.; Calhelha, R.C.; Silva, A.M.S.; Ferreira, I.C.F.R.; Cardoso, S.M. The Health-Benefits and Phytochemical Profile of Salvia apiana and Salvia farinacea var. victoria blue Decoctions. Antioxidants 2019, 8 .

21. Toplan, C.G.G.; Kurkcuoglu, M.; Goger, F.; Iscan, G.; Agalar, H.G.; Mat, A.; Baser, K.H.C.; Koyuncu, M.; Sarıyar, G. Composition and biological activities of Salvia veneris Hedge growing in Cyprus. Ind. Crops Prod. 2017, 97, 41-48. [CrossRef]

22. Ben Farhat, M.; Landoulsi, A.; Chaouch-Hamada, R.; Sotomayor, J.A.; Jordán, M.J. Characterization and quantification of phenolic compounds and antioxidant properties of Salvia species growing in different habitats. Ind. Crops Prod. 2013, 49, 904-914. [CrossRef]

23. Kozics, K.; Klusová, V.; Srančíková, A.; Mučaji, P.; Slameňová, D.; Hunáková, L'.; Kusznierewicz, B.; Horváthová, E. Effects of Salvia officinalis and Thymus vulgaris on oxidant-induced DNA damage and antioxidant status in HepG2 cells. Food Chem. 2013, 141, 2198-2206. [CrossRef]

24. Kostic, M.; Petrovic, M.B.; Jevtovic, T.; Jovic, M.; Petrovic, A.; Slavoljub, Ž. Anti-inflammatory effect of the Salvia sclarea L. ethanolic extract on lipopolysaccharide-induced periodontitis in rats. J. Ethnopharmacol. J. 2017, 199, 52-59. [CrossRef] [PubMed]

25. Bahadori, M.B.; Dinparast, L.; Zengin, G.; Sarikurkcu, C.; Bahadori, S.; Asghari, B.; Movahhedin, N. Functional components, antidiabetic, anti-Alzheimer's disease, and antioxidant activities of Salvia syriaca $\mathrm{L}$. Int. J. Food Prop. 2017, 20, 1761-1772. [CrossRef] 
26. Bahadori, M.B.; Asghari, B.; Dinparast, L.; Zengin, G.; Sarikurkcu, C.; Abbas-Mohammadi, M.; Bahadori, S. Salvia nemorosa L.: A novel source of bioactive agents with functional connections. Food Sci. Thecnology 2017, 75, 42-50. [CrossRef]

27. Biswas, S.K. Does the Interdependence between Oxidative Stress and Inflammation Explain the Antioxidant Paradox? Oxid. Med. Cell. Longev. 2016, 2016, 17-19. [CrossRef] [PubMed]

28. Ravipati, A.S.; Zhang, L.; Koyyalamudi, S.R.; Jeong, S.C.; Reddy, N.; Bartlett, J.; Smith, P.T.; Shanmugam, K.; Münch, G.; Wu, M.J.; et al. Antioxidant and anti-inflammatory activities of selected Chinese medicinal plants and their relation with antioxidant content. BMC Complement. Altern. Med. 2012, 12, 173. [CrossRef] [PubMed]

29. Joe, Y.; Zheng, M.; Kim, H.J.; Kim, S.; Uddin, M.J.; Park, C.; Ryu, D.G.; Kang, S.S.; Ryoo, S.; Ryter, S.W.; et al. Salvianolic acid B exerts vasoprotective effects through the modulation of heme oxygenase- 1 and arginase activities. J. Pharmacol. Exp. Ther. 2012, 341, 850-858. [CrossRef]

30. Jang, H.H.; Cho, S.Y.; Kim, M.J.; Kim, J.B.; Lee, S.H.; Lee, M.Y.; Lee, Y.M. Anti - inflammatory effects of Salvia plebeia R. Br extract in vitro and in ovalbumin - induced mouse model. Biol. Res. 2016, 1-11. [CrossRef]

31. Akkol, E.K.; Göger, F.; Koşar, M.; Başer, K.H.C. Phenolic composition and biological activities of Salvia halophila and Salvia virgata from Turkey. Food Chem. 2008, 108, 942-949. [CrossRef]

32. Moharram, F.A.-E.; Marzouk, M.S.; El-Shenawy, S.M.; Gaara, A.H.; El Kady, W.M. Polyphenolic profile and biological activity of Salvia splendens leaves. J. Pharm. Pharmacol. 2012, 64, 1678-1687. [CrossRef]

33. Boukhary, R.; Raafat, K.; Ghoneim, A.I.; Aboul-ela, M.; El-lakany, A. Anti-Inflammatory and Antioxidant Activities of Salvia fruticosa: An HPLC Determination of Phenolic Contents. Evidence-based Complement. Altern. Med. 2016, 2016. [CrossRef]

34. Ibrahim, T. a Chemical composition and biological activity of extracts from Salvia bicolor Desf. growing in Egypt. Molecules 2012, 17, 11315-11334. [CrossRef] [PubMed]

35. Liu, H.; Ma, S.; Xia, H.; Lou, H.; Zhu, F.; Sun, L. Anti-inflammatory activities and potential mechanisms of phenolic acids isolated from Salvia miltiorrhiza f. alba roots in THP-1 macrophages. J. Ethnopharmacol. 2018, 222, 201-207. [CrossRef] [PubMed]

36. Jiang, Y.; Zhang, L.; Rupasinghe, H.P.V. Antiproliferative effects of extracts from Salvia officinalis L. and Saliva miltiorrhiza Bunge on hepatocellular carcinoma cells. Biomed. Pharmacother. 2017, 85, 57-67. [CrossRef]

37. Shahneh, F.Z.; Baradaran, B.; Orangi, M.; Zamani, F. In vitro Cytotoxic Activity of Four Plants Used in Persian Traditional Medicine. Adv. Farm. Bull. 2013, 3, 453-455.

38. Ferreira, F.M.; Dinis, L.T.; Azedo, P.; Galhano, C.I.C.; Simões, A.; Cardoso, S.M.; Domingues, M.R.M.; Pereira, O.R.; Palmeira, C.M.; Peixoto, F.P. Antioxidant capacity and toxicological evaluation of Pterospartum tridentatum flower extracts. CyTA - J. Food 2012, 10, 92-102. [CrossRef]

39. Pereira, O.R.; Silva, A.M.S.; Domingues, M.R.M.; Cardoso, S.M. Identification of phenolic constituents of Cytisus multiflorus. Food Chem. 2012, 131, 652-659. [CrossRef]

40. Afonso, A.F.; Pereira, O.R.; Neto, R.T.; Silva, A.M.S.; Cardoso, S.M. Health-promoting effects of Thymus herba-barona, Thymus pseudolanuginosus, and Thymus caespititius decoctions. Int. J. Mol. Sci. 2017, 18, 1879. [CrossRef]

41. Afonso, A.F.; Pereira, O.R.; Válega, M.; Silva, A.M.S.; Cardoso, S.M. Metabolites and biological activities of Thymus zygis, Thymus pulegioides, and Thymus fragrantissimus grown under organic cultivation. Molecules 2018, 23, 1514. [CrossRef]

42. Shami, A.M.M.; Philip, K.; Muniandy, S. Synergy of antibacterial and antioxidant activities from crude extracts and peptides of selected plant mixture. BMC Complement. Altern. Med. 2013, 13, 1-11. [CrossRef]

43. Catarino, M.D.; Silva, A.M.S.; Saraiva, S.C.; Sobral, A.J.F.N.; Cardoso, S.M. Characterization of phenolic constituents and evaluation of antioxidant properties of leaves and stems of Eriocephalus africanus. Arab. J. Chem. 2018, 11, 62-69. [CrossRef]

44. Martins, N.; Barros, L.; Santos-Buelga, C.; Henriques, M.; Silva, S.; Ferreira, I.C.F.R. Evaluation of bioactive properties and phenolic compounds in different extracts prepared from Salvia officinalis L. Food Chem. 2015, 170, 378-385. [CrossRef] [PubMed] 
45. Barros, L.; Ferreira, M.J.; Queiro, B.; Ferreira, I.C.F.R.; Baptista, P. Total phenols, ascorbic acid, $\beta$-carotene and lycopene in Portuguese wild edible mushrooms and their antioxidant activities. Food Chem. 2007, 103, 413-419. [CrossRef]

46. Souza, A.H.P.; Corrêa, R.C.G.; Barros, L.; Calhelha, R.C.; Santos-buelga, C.; Peralta, R.M.; Bracht, A.; Matsushita, M.; Ferreira, I.C.F.R. Phytochemicals and bioactive properties of Ilex paraguariensis: An in-vitro comparative study between the whole plant, leaves and stems. Food Res. Int. 2015, 78, 286-294. [CrossRef] [PubMed]

Sample Availability: Sample Availability: Not available.

(C) 2019 by the authors. Licensee MDPI, Basel, Switzerland. This article is an open access article distributed under the terms and conditions of the Creative Commons Attribution (CC BY) license (http://creativecommons.org/licenses/by/4.0/). 